\title{
Medical trigger teams for severely ill medical patients in the Emergency Department
}

\author{
Stefan Posth", Mette Worsøe, Annmarie T Lassen \\ From 6th Danish Emergency Medicine Conference \\ Odense, Denmark. 20-21 November 2014
}

\section{Background}

Medical patients who arrive severely ill at the Emergency Department (ED) need to be diagnosed and treated immediately, as prognosis decreases rapidly with time spent before correct treatment is given for most of these patients.

At Odense University Hospital, patients arriving at the ED with either a pulse rate $>140$, systolic blood pressure $<80 \mathrm{mmHg}$, Glasgow Coma Scale $<9$, respiratory frequency $>35$ or $<8$ or a saturation $<80 \%$ are met by the medical trigger team. Patients with suspected apoplexy, STEMI or orthopedic multitrauma are met by other specialized teams.

\section{Objectives}

To describe frequency, patient characteristics, and 7 day $18 \%$ (95\% CI 16-21\%), 9\% (95\% CI 6-13\%) and 7\% (95\% CI $5-11 \%)$.

\section{Conclusion}

Medical trigger teams were used median twice a day. Their patients have a higher mortality than patients met by the thrombolysis or orthopedic multitrauma teams.

Published: 16 July 2015

doi:10.1186/1757-7241-23-S1-A51

Cite this article as: Posth et al:: Medical trigger teams for severely ill medical patients in the Emergency Department. Scandinavian Journal of Trauma, Resuscitation and Emergency Medicine 2015 23(Suppl 1):A51. mortality for adult patients ( $>18$ years) managed by medical trigger teams, thrombolysis, and orthopedic trauma teams.

\section{Methodology}

All patients who were met by a medical trigger team, a thrombolysis, or an orthopedic trauma team at arrival to the ED, Odense University Hospital between April 1st 2012 and May 31th 2013 were included.

\section{Results}

A total of 884 patients were met by the medical trigger team, 306 by the thrombolysis and 377 by the orthopedic multitrauma team. The median (range) number of team activations per day was $2(0-9), 0(0-6)$, and $1(0-6)$. Median age (25-75\%) was 70 (56-80), 67 (54-76), and 42 years (26-59), 54\% (95\% CI 50\%-57\%), 53\% (95\% CI 48-59\%), and $73 \%$ (95\% CI 68-78\%) were male, 7 day mortality was

\footnotetext{
* Correspondence: stefan.posth@rsyd.dk

Department of Emergency Medicine, OUH Odense University Hospital, Odense, Denmark
}

Submit your next manuscript to BioMed Central and take full advantage of:

- Convenient online submission

- Thorough peer review

- No space constraints or color figure charges

- Immediate publication on acceptance

- Inclusion in PubMed, CAS, Scopus and Google Scholar

- Research which is freely available for redistribution 